\title{
STUDI KOMPARASI METODE EKSPERIMEN BERBASIS INKUIRI DAN VERIFIKASI TERHADAP KETERAMPILAN GENERIK SAINS
}

\author{
Eltarizky Fatma ${ }^{{ }^{*}}$ dan Lisa Utami ${ }^{1}$ \\ 1. Program Studi Pendidikan Kimia, Fakultas Tarbiyah dan Keguruan, Universitas Islam Negeri \\ Sultan Syarif Kasim Riau, Jl. H. R Soebrantas No. 155 KM 15 Simpang Baru Panam, \\ Pekanbaru, 28293, Indonesia \\ *E-mail: eltarizkyfatma@gmail.com
}

\begin{abstract}
ABSTRAK
Penelitian ini merupakan penelitian kuasi eksperimen dengan rancangan Pretest-Posttest design yang dilakukan terhadap dua kelas. Penelitian ini dilatarbelakangi karena masih rendahnya keterampilan generik sains siswa kelas XI IPA di SMA Negeri 2 Tambang, Provinsi Riau. Tujuan dari penelitian ini untuk mengetahui apakah ada perbedaan keterampilan generik sains siswa pada kelas yang diberi perlakuan metode eksperimen berbasis inkuiri terbimbing dengan yang diberi perlakuan metode eksperimen berbasis verifikasi pada materi larutan penyangga. Populasi pada penelitian ini berjumlah 198 orang, di mana pengambilan sampel menggunakan teknik simple random sampling. Hasil analisis menunjukkan selisih rata-rata keterampilan generik sains siswa sebelum dilakukan eksperimen hanya sebesar 1,061, sedangkan setelah dilakukan eksperimen memiliki selesih sebesar 4,091. Analisis data akhir pada penelitian ini menggunakan uji " $t$ ", maka diperoleh nilai thitung $=2,204$ dan $t_{\text {tabel }}=1,999$ atau dengan nilai sig $<0,05$. Nilai thitung $>t_{\text {tabel, }}$ sehingga $\mathrm{H}_{\mathrm{o}}$ ditolak, yang berarti menunjukkan bahwa terdapat perbedaan keterampilan generik sains siswa pada kelas yang diberi perlakuan metode pembelajaran eksperimen berbasis inkuiri terbimbing dengan verifikasi.
\end{abstract}

Kata kunci: keterampilan generik sains (KGS), model inkuiri, metode eksperimen berbasis inkuiri terbimbing, metode eksperimen berbasis verifikasi.

\begin{abstract}
This research was quasi experiment research with Pretest-Posttes plans that was conducted in two groups. The research was instigated by the low of student science generic at the eleventh grade of IPA at State Senior High School 2 Tambang, Riau Province. The research aimed at knowing there was a difference between student science generic skill by using guidence inquiry based experiment method and verification on buffer lesson. Simple random sampling technique was used for collecting the data. The result of analysis data showed that avarage of science generic skills between the class before using the method was 1,061 and after using the method was 4,091. The final of analysis data by using test that was tobeservated 2,204 $>t_{\text {table }}$ was 1.999 or with the significance was $>0.05$. tobserved $>t_{\text {table. }}$ Ho was rejected, it means that there a difference between student science generic skills by using guidence inquiry based experiment method and verification method.
\end{abstract}

Keywords: science generic skills, inquiry model, guidence inquiry based experiment method, verification based experiment method.

DOI: https://doi.org/10.15575/jtk.v3i2.3386 


\section{PENDAHULUAN}

Perkembangan IPTEK dan semakin pesatnya perubahan global dalam berbagai aspek kehidupan menjadi tantangan bangsa dalam mempersiapkan generasi masa depan yang kaya akan keterampilan. Setiap manusia dibekali dengan keterampilan dasar yang dibawanya sejak lahir yang terdiri dari keterampilan berpikir, berbuat dan bersikap. Allah SWT berfirman dalam Al-Quran yang artinya: "Sungguh, kami telah menciptakan manusia dalam bentuk yang sebaik-baiknya" (Q. S. At-Tin: 4) (Departemen Agama RI, 2013).

Sesungguhnya Kami istimewakan manusia dengan akalnya, agar bisa berpikir dan menimba berbagai ilmu pengetahuan serta bisa mewujudkan segala inspirasinya yang dengannya manusia bisa berkuasa atas segala makhluk (Al-Maragi, 1993). Manusia memiliki kekuatan dan pengaruh yang dengan keduanya bisa menjangkau segala sesuatu. Manusia telah diciptakan dalam bentuk yang sempurna dan dibekali dengan bermacammacam potensi untuk dapat mengolah alam sesuai dengan amanah Allah. Oleh karena itu manusia seharusnya dapat mengembangkan potensi dan keterampilan dasar yang telah Allah berikan. Keterampilan itu bermacammacam jenisnya termasuk keterampilan generik.

Keterampilan generik merupakan salah satu keterampilan utama untuk peningkatan kualitas Sumber Daya Manusia (SDM) di abad 21 (Zulfiani, 2014). Keterampilan generik pada masa sekarang mendapat perhatian yang lebih karena berdasarkan hasil survei yang dilakukan oleh National Association of Colleges and Employers (NACE) pada tahun 2002 kepada 457 pemimpin perusahaan tentang kualitas terpenting seseorang, nilai kognitif hanya menduduki urutan ke-17, sedangkan lima kualitas terpenting secara berturut-turut adalah kemampuan berkomunikasi, kejujuran dan integritas, kemampuan bekerja sama, kemapuan interpersonal dan etika (Cahyono dan Subroto, 2013). Keterampilan Generik dalam bidang sains dikenal sebagai Keterampilan Generik Sains (KGS).

Keterampilan generik sains adalah strategi kognitif, afektif maupun psikomotor yang dapat dipelajari dan tertinggal dalam diri siswa (Liliasari dan Tawil, 2014). Keterampilan generik sains juga sebagai kemampuan dan atribut untuk hidup dan bekerja. Keterampilan generik sains dapat digunakan untuk semua jenis pekerjaan, termasuk kompetensi dasar atau kemampuan kunci yang mencakup kemampuan kognitif, personal dan interpersonal yang berhubungan dengan kepegawaian.

Keterampilan generik sains ada pada setiap pembelajaran sains termasuk dalam pembelajaran kimia. Keterampilan generik sains akan muncul pada pembelajaran yang berkaitan dengan teori-teori kimia maupun praktikum (Annisa dan Sudarmin, 2016). Ilmu kimia merupakan ilmu sains yang sangat kompleks, dalam ilmu kimia tentunya memerlukan keterampilan generik sains yang tinggi untuk memahami materinya yang dapat berupa konsep, hafalan dan hitungan.

Namun dalam kenyataannya keterampilan generik sains siswa di sekolah masih tergolong rendah. Hal ini dibuktikan dari studi pendahuluan yang penulis lakukan di SMAN 2 Tambang tepatnya di kelas XI IPA 3 didapatkan bahwa dari 13 indikator keterampilan generik sains yang disajikan

Jurnal Tadris Kimiya 3, 2 (Desember 2018): 145-157 
dalam angket siswa, hasilnya didapatkan lima indikator dalam kategori rendah dan dua indikator dalam kategori sangat rendah. Dengan demikian hanya $46 \%$ dari 30 orang responden yang memenuhi keterampilan generik sains dengan kategori sedang, tinggi hingga sangat tinggi.

Kegiatan praktikum di laboratorium dapat meningkatkan keterampilan generik (Saptorini, 2008). Keterampilan generik sains meliputi: (1) pengamatan langsung, (2) pengamatan tidak langsung (3) kesadaran tentang skala besaran, (4) bahasa simbolik, (5) logical frame, (6) konsistensi logis, (7) hukum sebab akibat, (8) permodelan matematika dan (9) inferensi logika (Brotosiswoyo, 2001). Metode pembelajaran praktikum atau eksperimen dapat berbasis verifikasi dan dapat pula berbasis inkuiri.

Pembelajaran inkuiri dibagi menjadi empat level, yakni inkuiri konfirmasi, inkuiri terstruktur, inkuiri terbimbing dan inkuiri bebas Banchi dan Bell (dalam Soleh dkk., 2014). Pemilihan inkuiri terbimbing dalam penelitian ini disebabkan karena pembelajaran inkuiri terbimbing merupakan model yang cocok untuk dibelajarkan pada pendidikan menengah dikarenakan model ini tidak terlalu memerlukan banyak waktu dalam menyelesaikan tahap pembelajarannya dan terdapat bimbingan guru untuk dapat mengarahkan peserta didik dalam belajar (Soleh dkk., 2014).

Sebelumnya terdapat beberapa penelitian yang meneliti tentang upaya peningkatan keterampilan generik sains siswa. Diantaranya yaitu penelitian yang mengembangkan keterampilan generik sains siswa dengan penerapan model Content Context Connection Researching Reasoning Reflecting (3C3R) pada konsep koloid dengan hasil bahwa penerapan model tersebut dapat mengembangkan keterampilan generik sains siswa (Burhanuddin dkk., 2018) dan penelitian yang melihat perbandingan metode eksperimen berbasis inkuiri dan verifikasi terhadap hasil belajar siswa kelas VII SMP pada mata pelajaran fisika, didapatkan hasil bahwa terdapat perbedaan yang signifikan hasil belajar siswa yang diajarkan dengan metode eksperimen berbasis inkuiri terbimbing dan verifikasi (Hidayatusholihah, 2013). Berdasarkan penelitian relevan diatas penulis ingin melihat apakah terdapat perbedaan keterampilan generik sains siswa yang diajarkan dengan metode eksperimen berbasis inkuiri terbimbing dan metode eksperimen berbasis verifikasi pada pembelajaran kimia khususnya pada materi larutan penyangga. Hal ini disebabkan kedua metode ini yang sering dilakukan di sekolah. Sehingga nantinya dalam pembelajaran dapat digunakan metode yang lebih efektif.

Pokok bahasan yang akan dilakukan eksperimen adalah pokok bahasan larutan penyangga. Larutan penyangga atau buffer adalah larutan yang apabila ditambahkan sedikit asam atau sedikit basa atau pengenceran dengan air tidak akan mengubah $\mathrm{pH}$ larutan tersebut secara berarti (Syukri, 1999). Larutan penyangga ini dapat dilakukan eksperimen diantaranya untuk menentukan campuran yang membentuk larutan penyangga dan menetukan $\mathrm{pH}$ larutan penyangga. Larutan penyangga ini terdiri dari campuran asam lemah dan basa konjugasinya atau basa lemah dengan asam konjugasinya (Ahmad, 1996).

Berdasarkan latar belakang yang telah dikemukakan, maka penelitian ini bertujuan untuk melihat perbedaan keterampilan generik sains siswa yang diajarkan dengan metode eksperimen berbasis inkuiri 

Inkuiri dan Verifikasi terhadap Keterampilan Generik Sains

terbimbing dan verifikasi. Penelitian ini dilakukan pada eksperimen materi larutan penyangga. Setelah melakukan karakterisasi pada materi larutan penyangga maka indikator keterampilan generik sains yang diukur pada penelitian ini adalah: pengamatan langsung, pengamatan tidak langsung, bahasa simbolik, kesadaaran akan skala dan bahasa simbolik.

\section{METODE PENELITIAN}

Penelitian ini merupakan jenis kuasi eksperimen yang dilakukan pada dua kelas di mana kelas eksperimen satu mendapat perlakuan eksperimen berbasis inkuiri terbimbing dan kelas eksperimen dua mendapat perlakuan eksperimen berbasis verifikasi. Desain penelitian ini adalah PretestPosttest Design. Penelitian ini dilakukan di SMA Negeri 2 Tambang pada bulan Maret sampai April 2017. Populasi terdiri dari 6 kelas yang berjumlah 198. Sedangkan Sampel terdiri dari dua kelas dengan total jumlah siswa 33 orang. Teknik pengambilan sampel menggunakan teknik simple random sampling. Teknik pengumpulan data adalah tes, observasi, angket dan dokumentasi. Tes berupa soal esai untuk mengukur keterampilan generik sains siswa yang terlebih dahulu di lakukan validasi isi dan validasi empiris kemudian dilihat reliabilitas, tingkat kesukaran, dan daya bedanya. Observasi digunakan untuk mendukung tes dalam melihat keterampilan generik sains siswa. Angket digunakan dalam studi pendahuluan dan dokumentasi digunakan untuk mendapatkan data-data dan hasil belajar siswa. Hasil dari penelitian ini diolah dengan menggunakan SPSS 25.00. Perbedaan langkah pembelajaran pada kelas eksperimen kesatu (eksperimen inkuiri) dan kedua (eksperimen verifikasi) dapat dilihat pada Tabel 1.
Tabel 1. Perbedaan Tahapan Pembelajaran Eksperimen Inkuiri dan Eksperimen Verifikasi

\begin{tabular}{|c|c|}
\hline \multicolumn{2}{|c|}{ Tahapan Pembelajaran } \\
\hline $\begin{array}{l}\text { Eksperimen } \\
\text { Inkuiri }\end{array}$ & $\begin{array}{c}\text { Eksperimen } \\
\text { Verifikasi }\end{array}$ \\
\hline $\begin{array}{l}\text { 1. Kegiatan awal } \\
\text { 2. Menyajikan masalah } \\
\text { (Mengerjakan soal } \\
\text { yang diberikan guru } \\
\text { sekaligus } \\
\text { merancang } \\
\text { eksperimen) } \\
\text { 3. Menyatakan } \\
\text { hipotesis } \\
\text { 4. Menguji hipotesis } \\
\text { (Eksperimen) } \\
\text { 5. Mengumpulkan } \\
\text { data } \\
\text { 6. Menganalisa data } \\
\text { 7. Merumuskan } \\
\text { Kesimpulan } \\
\text { (Menemukan teori) } \\
\text { 8. Kegiatan akhir }\end{array}$ & $\begin{array}{l}\text { 1. Kegiatan awal } \\
\text { 2. Menyajikan teori } \\
\text { (guru } \\
\text { menjelaskan) } \\
\text { 3. Menganalisa } \\
\text { penjelasan guru } \\
\text { 4. Melakukan } \\
\text { eksperimen yang } \\
\text { disiapkan guru } \\
\text { 5. Memverifikasi } \\
\text { penjelasan guru } \\
\text { dengan hasil } \\
\text { eksperimen } \\
\text { (Kesimpulan) } \\
\text { 6. Kegiatan akhir }\end{array}$ \\
\hline
\end{tabular}

\section{HASIL DAN PEMBAHASAN}

\subsection{Uji Homogenitas}

Dalam penelitian ini dibutuhkan dua sampel kelas yang memiliki kemampuan homogen. Oleh karena itu perlu dilakukan tes uji homogenitas dari siswa yang terbagi dalam enam kelas. Uji homogenitas dilakukan berdasarkan data nilai siswa pada ulangan sebelumnya yaitu pada meteri asam basa. Uji homogenitas dilakukan dengan menggunakan metode bartlet dengan SPSS versi 25.0 for windows dengan prosedur classify determinant yakni analisis manova prints bartlett-box $f$ test statistic dengan hasil test results diperoleh nilai box's $M$ diperoleh 8,735 dengan nilai sig. $0,125>0,05$, maka Jurnal Tadris Kimiya 3, 2 (Desember 2018): 145-157 
dapat disimpulkan bahwa sampel berasal dari populasi yang homogen. Hal ini berarti keenam kelompok sampel memiliki varians yang sama (homogen). Jadi, dapat disimpulkan bahwa ketika dilakukan pembelajaran dengan menggunakan metode yang berbeda terhadap kedua sampel, apabila terjadi perbedaan keterampilan generik sains siswa yang berbeda antara kedua sampel tersebut bukan karena kemampuan dasar yang berbeda tetapi karena penggunaan metode yang berbeda.

\subsection{Analisis Butir Soal}

Sebelum melakukan penelitian ini, peneliti terlebih dahulu perlu mengetahui soal tes yang digunakan sebagai instrumen tersebut baik atau tidak digunakan sebagai soal tes. Untuk itu, soal yang digunakan untuk pretest dan postest harus diujikan terlebih dahulu dan kemudian dilakukan analisis butir soal. Hal ini untuk melihat kriteria validitas, reliabilitas, tingkat kesukaran dan daya pembeda soal yang diinginkan sehingga baik digunakan sebagai instrumen dalam penelitian ini. Jumlah soal yang diujikan sebanyak soal dalam bentuk soal esai yang mana pengujiannya dilakukan di kelas XII IPA 3 dengan jumlah peserta didik 30 orang. Pada pengujian validitas, peneliti menggunakan validitas isi dan butir, di mana inti dari validitas butir adalah soal dikatakan valid apabila soal tersebut telah memenuhi sesuatu yang diukur (indikator). Berdasarkan hasil analisis, didapatkan bahwa tujuh soal dinyatakan valid sedangkan dari tiga soal lainnya dinyatakan gugur atau tidak valid. Soal yang dinyatakan valid terdiri dari satu soal untuk indikator pengamatan langsung, dua soal untuk indikator pengamatan tidak langsung, satu soal untuk indikator kesadaran akan skala, satu soal untuk indikator bahasa simbolik dan dua soal untuk indikator permodelan matematika. Berdasarkan hasil analisis reliabilitas soal, diperoleh reliabilitas tes sebesar 0,851 dengan kriteria sangat tinggi.

Pengujian tingkat kesukaran soal sangat diperlukan dalam tes keterampilan generik sains siswa, hal ini untuk mengetahui apakah soal tersebut termasuk dalam soal yang memiliki kriteria sukar hingga soal yang memiliki kriteria mudah, sehingga peneliti dapat menentukan soal yang layak digunakan dalam penelitian ini.

Berdasarkan hasil analisis tahap I diperoleh tingkat kesukaran soal dengan kriteria mudah sebanyak 30\%, kriteria sedang sebanyak 50\% dan kriteria sukar sebanyak 20\%. Gambaran tingkat kesukaran soal yang termasuk kategori-kategori tersebut bisa dilihat pada Gambar 1.

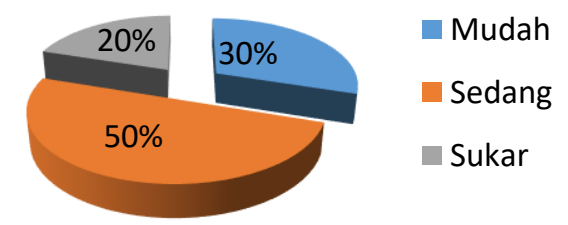

\section{Gambar 1. Diagram Tingkat Kesukaran Soal Tes Tahap I}

Berdasarkan hasil analisis tes tahap II diperoleh juga ada yang termasuk kategori soal sukar, sedang dan mudah. Pengujian tes tahap II diketahui soal dengan kriteria mudah persentasenya 29\% dengan jumlah soal sebanyak dua soal, kriteria sedang persentasenya $42 \%$ dengan jumlah soal sebanyak tiga soal dan kriteria sukar persentasenya $29 \%$ dengan jumlah soal sebanyak dua soal. Gambaran hasil tingkat kesukaran soal yang diperoleh pada tes tahap kedua bisa dilihat pada Gambar 2 . 


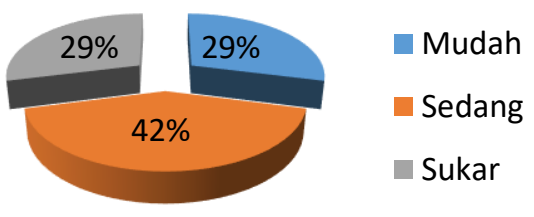

\section{Gambar 2. Diagram Tingkat Kesukaran Soal Tes Tahap II}

Begitu juga dengan pengujian daya pembeda soal, hal ini untuk mengetahui kesanggupan soal dalam membedakan peserta didik yang tergolong mampu (tinggi prestasinya) dengan peserta didik yang tergolong kurang atau lemah prestasinya. Daya pembeda soal tes pada tahap I diperoleh dari kategori daya pembeda bagus sekali sampai kategori daya pembeda soal yang jelek dan harus dibuang. Berdasarkan hasil analsis diperoleh kriteria daya sangat baik sebesar 30\%, dengan kriteria daya pembeda baik sebesar $40 \%$, dengan kriteria daya pembeda jelek sebesar $30 \%$. Gambaran hasil daya pembeda soal yang diperoleh bisa dilihat pada Gambar 3 .

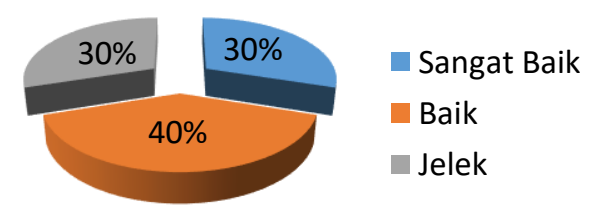

\section{Gambar 3. Diagram Daya Pembeda Soal Tes Tahap I}

Pada pengujian instrumen tahap kedua, nilai daya pembeda soal yang diperoleh hanya yang digunakan adalah kriteria sangat baik dan baik. Daya pembeda soal yang termasuk kriteria soal sangat baik terdapat pada item soal nomor 2, 7 dan 8 (sebesar 43\%), dan daya pembeda soal kriteria baik terdapat pada nomor 1, 3, 6, dan 9 (sebesar 57\%), 150 sedangkan kriteria daya pembeda soal jelek tidak digunakan pada pengujian soal tahap II ini. Gambaran hasilnya bisa dilihat pada Gambar 4.

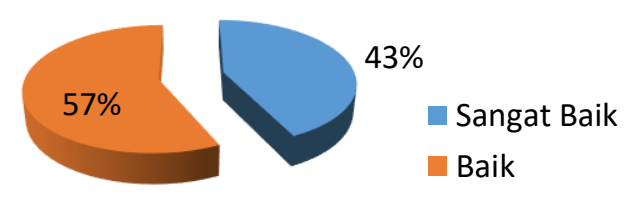

\section{Gambar 4. Diagram Daya Pembeda Soal Tes Tahap II}

Berdasarkan hasil tersebut didapatkan soal yang daya pembedanya bisa digunakan untuk sebagai instrumen penelitian sebanyak tujuh soal, yakni dua soal kategori tingkat kesukaran mudah, tiga soal kategori tingkat kesukaran sedang, dan dua soal kategori tingkat kesukaran sukar. Berdasarkan dari seluruh hasil analisis soal yang diuji cobakan, maka diperoleh tujuh soal memenuhi empat kriteria yaitu validitas, reliabilitas, tingkat kesukaran dan daya pembedanya, sehingga dapat digunakan sebagai instrumen dalam penelitian ini.

\subsection{Analisis Akhir}

Hasil analisis akhir data mendukung rumusan masalah yang diajukan, yaitu terdapat perbedaan keterampilan generik sains siswa yang diajarkan dengan menggunakan metode pembelajaran eksperimen berbasis inkuiri terbimbing dengan metode pembelajaran eksperimen berbasis verifikasi pada materi larutan penyangga.

Jika dilihat dari nilai rata-rata pretest dan postest maka perbedaannya seperti yang ditunjukkan oleh Gambar 5.

Jurnal Tadris Kimiya 3, 2 (Desember 2018): 145-157 


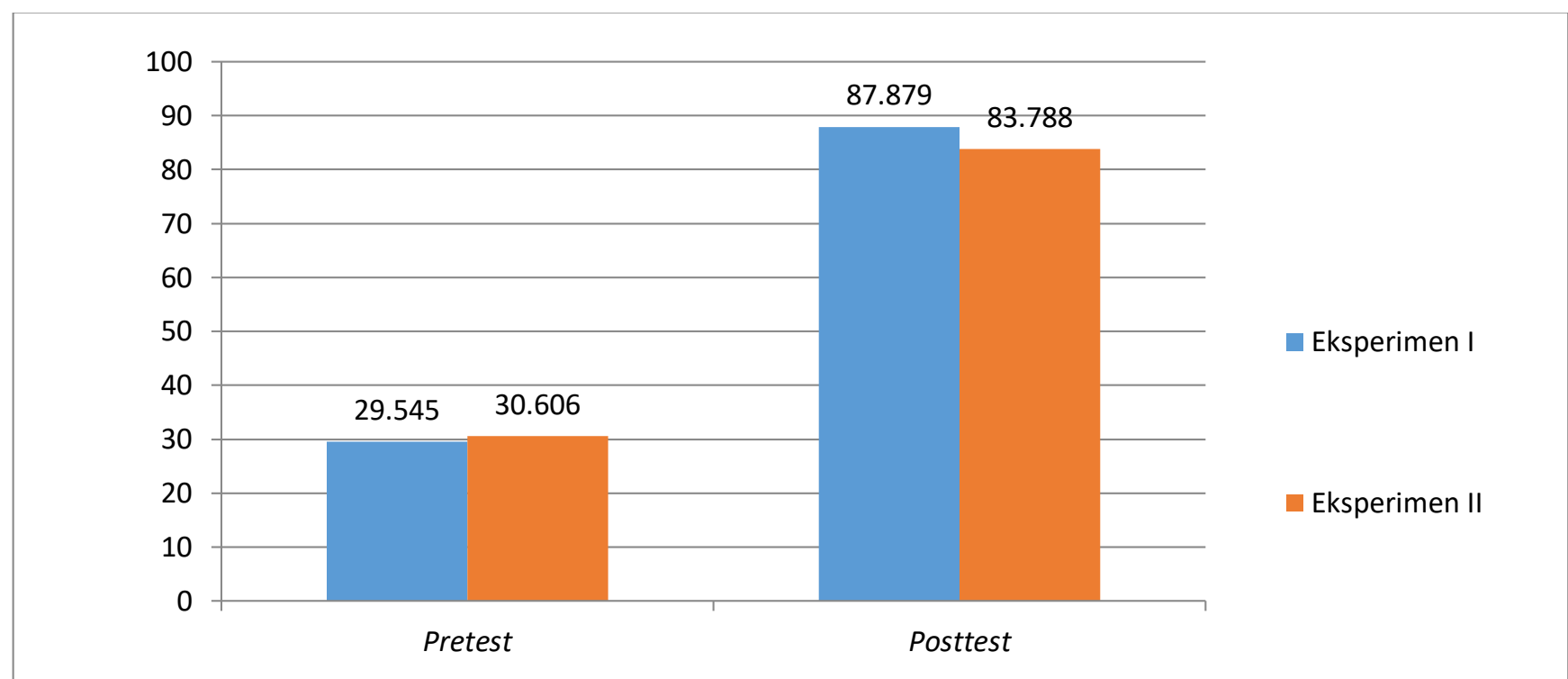

Gambar 5. Diagram Perbandingan Nilai Kelas Eksperimen I dan Eksperimen II

Berdasarkan Gambar 5 dapat dilihat perbandingan antara kelas eksperimen I dan kelas eksperimen II. Kedua kelas awalnya sama-sama memiliki nilai pretest yang hampir sama hingga akhirnya mendapatkan hasil posttest lebih tinggi pada kelas eksperimen yang menggunakan metode pembelajaran eksperimen berbasis inkuiri terbimbing dibandingkan kelas eksperimen II yang menggunakan metode pembelajaran eksperimen berbasis verifikasi yang mana selisih rata-rata keterampilan generik sains siswa sebelum dilakukan eksperimen hanya sebesar 1,061, sedangkan setelah dilakukan eksperimen memiliki selisih sebesar 4,091. Hal ini dikarenakan pada kelas eksperimen I siswa dilatih lebih baik daripada kelas eksperimen II. Pada kelas eksperimen I siswa diminta merancang dan melakukan eksperimen sendiri dengan pengawasan guru sedangkan pada kelas eksperimen II siswa hanya diminta untuk melakukan eksperimen yang telah disiapkan guru dan memverifikasi hasil yang didapat dengan teori yang telah diajarkan sebelumnya. Hasil ini sesuai dengan penelitian yang dilakukan Nurcahyo dkk. (2014) di mana terdapat perbedaan hasil belajar yang signifikan antara kelas yang diajarkan dengan metode eksperimen berbasis inkuiri terbimbing ( $N$-gain 55.81) dan eksperimen berbasis verifikasi ( $N$-gain 43.17) pada materi sistem pernapasan. Serta sesuai pula dengan penelitian yang dilakukan oleh Darmawan dkk. (2013) di mana pelaksanaan eksperimen berbasis inkuiri dapat meningkatkan pemahaman siswa dan keterampilan generik sains siswa secara signifikan dibandingkan metode eksperimen verifikasi pada materi fluida statis.

Untuk melihat perbedaan keterampilan generik sains siswa kelas eksperimen I dan II berdasarkan indikator-indikator yang diukur dapat dilihat pada Gambar 6, Gambar 7 dan Gambar 8. 

Inkuiri dan Verifikasi terhadap Keterampilan Generik Sains

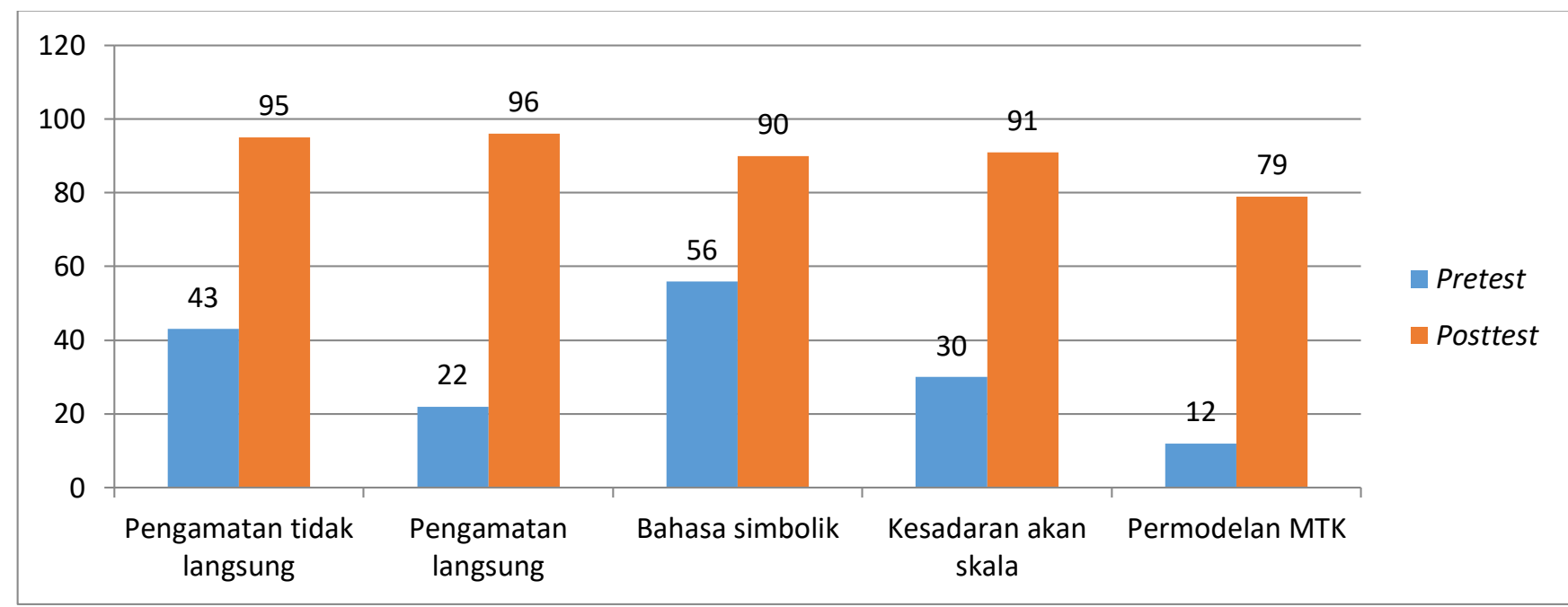

Gambar 6. Persentase Hasil Pretest dan Posttest Keterampilan Generik Sains Siswa Kelas Esperimen I

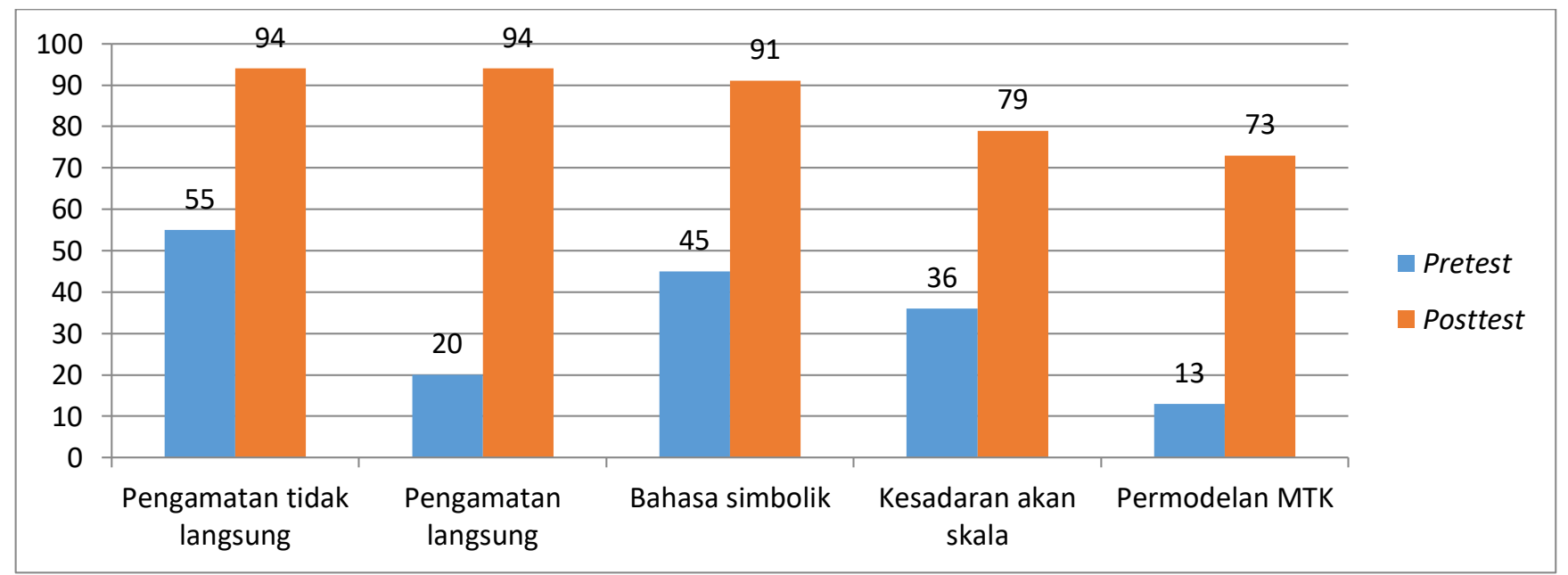

Gambar 7. Persentase Hasil Pretest dan Posttest Keterampilan Generik Sains Siswa Kelas Esperimen II 


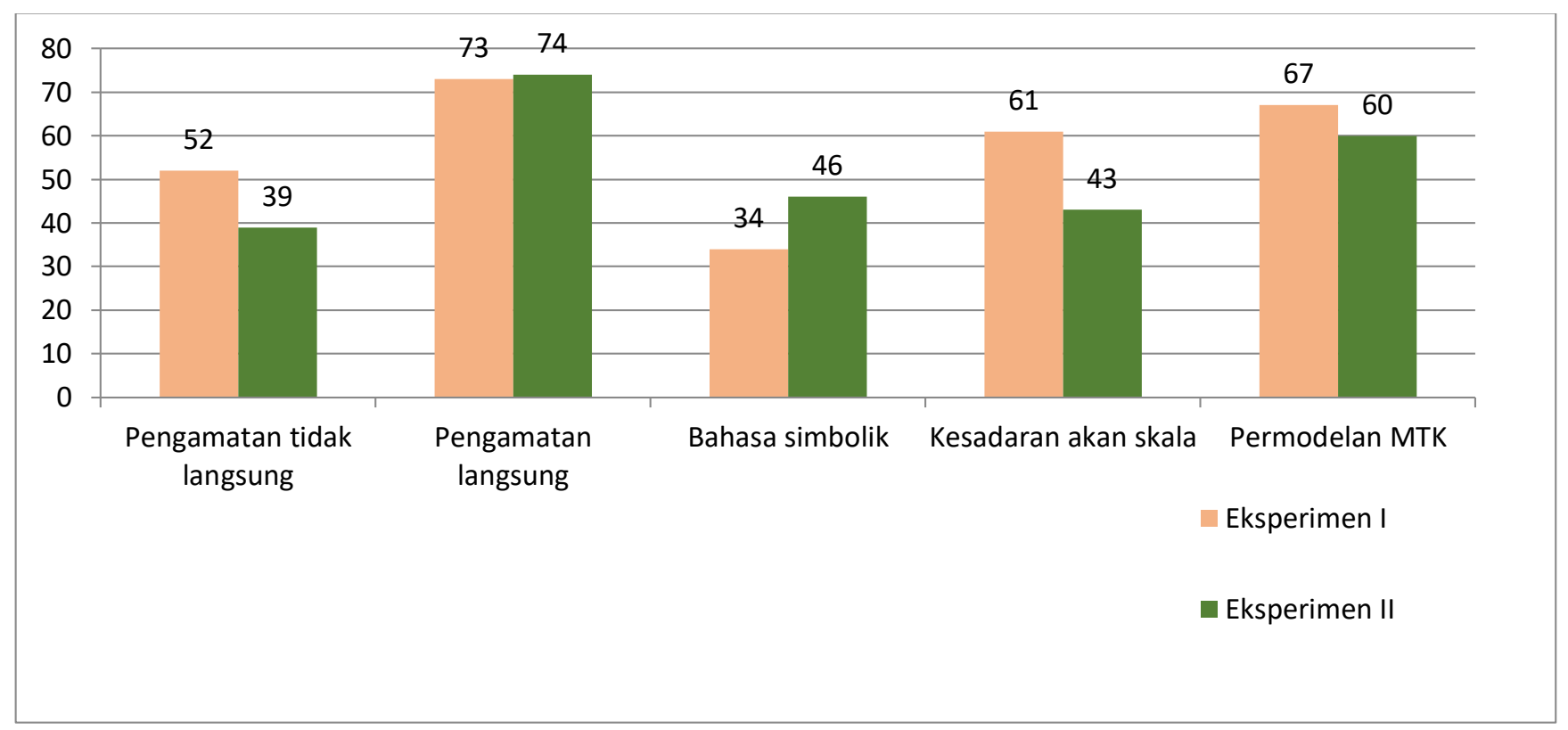

\section{Gambar 8. Persentase Hasil Pretpost Keterampilan Generik Sains Siswa Kelas Esperimen I dan Kelas Eksperimen II}

Secara umum peningakatan keterampilan generik sains yang tertinggi terdapat pada kelas eksperimen I yang menggunakan metode eksperimen berbasis inkuiri terbimbing. Hal ini sesuai dengan penelitian yang dilakukan oleh Septiani dan Sumarni (2015) yang menyatakan bahwa penerapan model Inquiry Based Learning berpengaruh pada peningkatan keterampilan generik sains siswa yaitu sebesar 12,08\%. Hal ini disebabkan karena tahapan pada eksperimen berbasis inkuiri terbimbing ini lebih mendorong siswa belajar menemukan konsep yang akan dieksperimenkan sedangkan pada eksperimen berbasis verifikasi siswa hanya membuktikan konsep yang telah dipelajari dan telah dijelaskan oleh guru sebelumnya.

Peningkatan KGS yang lebih besar pada kelas eksperimen I dikarenakan praktikum yang dilakukan merupakan hasil dari implementasi rancangan prosedur yang mereka buat sendiri, sehingga mereka dapat menemukan konsep dan membuktikan konsepnya pada praktikum tersebut. Meskipun menggunakan 153 metode yang berbeda, pada kelas eksperimen II juga mengalami peningkatan KGS. Hal ini disebabkan siswa juga dilatih oleh guru dalam mengembangan keterampilan generik sainsnya melalui praktikum yang dipimpin guru dan praktikumnya bersifat membuktikan teori yang telah diajarkan guru sebelumnya. Indikator keterampilan generik sains yang mengalami peningkatan tertinggi yaitu indikator pengamatan langsung. $\mathrm{Hal}$ ini sesuai dengan yang dinyatakan oleh Brotosiswoyo (2001) bahwa pengamatan langsung merupakan salah satu indikator keterampilan generik sains yang mudah dikuasai. Meskipun antara kedua kelas eksperimen tidak terlalu besar perbedaan peningkatannya, peningkatan ini disebabkan kedua kelas sama-sama menggunakan metode eksperimen. Metode eksperimen mendorong siswa untuk menggunakan segala panca inderanya dalam mengamati fenomena yang terjadi dan mendorong siswa untuk jeli melihat persamaan dan perbedaan yang terjadi dalam eksperimen. Hal ini juga Jurnal Tadris Kimiya 3, 2 (Desember 2018): 145-157 
didukung oleh hasil observasi keterampilan generik sains siswa pada kedua kelas yang menunjukkan bahwa indikator yang mendapatkan rata-rata tertinggi adalah indikator pengamatan langsung.

Indikator yang juga mengalami peningkatan adalah indikator permodelan matematika. Kelas yang mengalami peningkatan lebih tinggi adalah kelas eksperimen I. Hal ini disebabkan penyusunan dan format lembar penuntun praktikum yang berbeda dengan kelas eksperimen II. Pada penuntun praktikum kelas eksperimen I siswa diajak untuk berhitung diawal saat akan merancang eksperimen. Sehingga siswa akan lebih paham tentang konsep perhitungannya dari pada kelas eksperimen II.

Indikator selanjutnya yang mengalami peningkatan adalah indikator kesadaran akan skala dan indikator bahasa simbolik. Pada indikator kesadaran akan skala peningkatan terbesar juga terdapat pada kelas ekeperimen I. Hal ini dapat disebabkan ketelitian siswa pada kelas eksperimen I dalam membaca skala sebab pada kelas eksperimen I siswa dituntut untuk membuktikan hipotesisnya dan siswa akan lebih cermat mengamati skala agar hasil yang didapatkan sesuai dengan hipotesis yang mereka buat. Hal ini sejalan dengan hasil penelitian yang dilakukan Septiani dan Sumarni (2015) yang menyatakan bahwa pada kelas eksperimen berbasis verifikasi siswa hanya mengikuti praktikum yang telah dipersiapkan oleh gurunya sehingga membuat siswa malas untuk mencari informasi terkait kegiatan praktikum yang akan dilakukan. Akibatnya siswa kurang dapat memahami kegiatan praktikum dengan baik, dan ketika melakukan praktikum waktu siswa lebih banyak digunakan untuk bertanya kepada gurunya. Dengan keterbatasan waktu mengakibatkan siswa tergesa-gesa untuk menyelesaikan kegiatan praktikum, yang mengakibatkan siswa kurang teliti dalam melakukan pengukuran (Septiani dan Sumarni, 2015). Indikator bahasa simbolik berfungsi untuk menggambarkan simbol, dalam pembelajaran sains. Misalnya dalam mengenal lambang unsur, persamaan reaksi dan simbol-simbol lainnya (Rimatusodik, 2010). Hasil penelitian menunjukkan bahwa kelas eksperimen II mendapatkan nilai lebih tinggi dari pada kelas eksperimen I. Hal ini disebabkan pada kelas eksperimen II siswa memiliki waktu yang lebih banyak dari kelas eksperimen I sehingga siswa fokus pada eksperimen dan bahan-bahannya beserta lambang yang tercantum pada setiap botolnya.

Indikator pengamatan tidak langsung juga mengalami peningkatan di mana kelas eksperimen I mendapatkan hasil lebih tinggi dibandingkan kelas eksperimen II. Hal ini disebabkan pada tahapan pembelajaran di eksperimen I siswa merancang sendiri percobaannya termasuk alat apa saja yang akan digunakan sehigga siswa sudah tau sebelum dilakukan nya eksperimen ditambah pengetahuan yang didapat selama eksperimen. Hal ini sesuai dengan penelitian yang dilakukan Yuliyanti dkk. (2016) yang menyatakan bahwa melalui tahapan orientasi inkuiri siswa dapat merancang dan belajar menggunakan alat yang akan digunakan dalam eksperimen.

Indikator bahasa simbolik mendapatkan hasil yang berbeda, di mana kelas eksperimen II mendapat nilai lebih tinggi dari pada kelas eksperimen I. Hal ini dapat disebakan karena pada kelas eksperimen II siswa dituntut untuk memverifikasi teori yang telah disampaikan guru. Sehingga siswa dapat fokus pada percobaan dan teliti pada simbol dan 

Inkuiri dan Verifikasi terhadap Keterampilan Generik Sains

lambang kimia tanpa harus memikirkan hasil dari percobaan tersebut. Hal ini senada dengan penelitian yang dilakukan oleh Septiani (2015) yang menyatakan pada kelas dengan metode eksperimen berbasis inkuiri lebih terpusat pada kegiatan eksperimen, sedangkan kelas eksperimen berbasis verifikasi lebih teliti dalam menuliskan bahasa-bahasa simbolik karena dalam melakukan kegiatan praktikum semuanya dipersiapkan oleh gurunya.

\section{KESIMPULAN}

Terdapat perbedaan keterampilan generik sains siswa yang diajarkan dengan menggunakan metode pembelajaran eksperimen berbasis inkuiri terbimbing dengan siswa yang diajarkan dengan metode pembelajaran eksperimen berbasis verifikasi pada materi larutan penyangga. Berdasarkan perhitungan didapatkan nilai t hitung $>$ tabel $(2,204>1,999)$ atau nilai sig $<0,05$ dengan demikian Ho ditolak dan Ha diterima. 
Studi Komparasi Metode Eksperimen Berbasis Inkuiri dan Verifikasi terhadap Keterampilan Generik Sains

\section{DAFTAR PUSTAKA}

Ahmad, H. (1996). Kimia Larutan. Bandung: PT Citra Aditya Bakti.

Al-Maragi, A. M. (1993). Terjemah Tafsir AlMaragi 28. Semarang: PT Karya Toha Putra.

Annisa, N. H., \& Sudarmin, S. (2016). Pengaruh Pembelajaran Guided Inquiry Berbantuan Diagram Vee Terhadap Keterampilan Generik Sains Siswa. Jurnal Inovasi Pendidikan Kimia, 10(1).

Brotosiswoyo, B. S. (2001). Hakikat Pembelajaran Fisika di Perguruan Tinggi. Jakarta: Depdiknas.

Burhanuddin, R., Subarkah, C. Z., \& Sari. (2018). Penerapan Model Pembelajaran Content Context Connection Researching Reasoning Reflecting (3C3R) untuk Mengembangkan Keterampilan Generik Sains Siswa pada Konsep Koloid. Jurnal Tadris Kimiya, 3(1).

Cahyono, E., \& Subroto, T. (2013). Penggunaan Buku Saku Praktikum Kimia untuk Meningkatkan Kerja Ilmiah dan Keterampilan Generik. Chemistry in Education, 2(1).

Darmawan, J., Halim, A., \& Nur, S. (2013). Metode Pembelajaran Eksperimen Berbasis Inkuiri untuk Meningkatkan Pemahaman Konsep dan Keterampilan Generik Sains Siswa SMA. Jurnal Pendidikan Sains Indonesia, 1(1), 22-33.

Departemen Agama RI. (2013). Al-quran dan Terjemahannya. Jakarta: CV Darus Sunnah.
Hidayatusholihah, N. (2013). Studi Komparasi Antara Hasil Belajar IPA Siswa yang Diajarkan dengan Metode Eksperimen Berbasis Inkuiri Terbimbing dan Verifikasi pada Siswa Kelas VII Semester Genap SMP N 4 Purworejo Tahun Pelajaran 2012/2013. RADIASI: Jurnal Berkala Pendidikan Fisika, 3(2), 166-169.

Liliasari \& Tawil, M. (2014). KeterampilanKeterampilan Sains dan Implementasinya dalam Pembelajaran IPA. Makassar: UNM.

Nurcahyo, S. D., Pramudiyanti, P., \& Bintoro, A. (2014). Perbandingan Metode Eksperimen Inkuiri Dengan Verifikasi Terhadap Hasil Belajar Materi Sistem Pernapasan. Jurnal Bioterdidik: Wahana Ekspresi Ilmiah, 2(8).

Rimatusodik, R. (2010). Profil Keterampilan Generik Siswa SMP dalam Praktikum Kerusakan Lingkungan Menggunakan Kotak Erosi. Skripsi. Sarjana UPI, 4.

Saptorini. (2008). Peningkatan Keterampilan Generik Sains Bagi Mahasiswa Melalui Perkuliahan Praktikum Kimia Analisis Instrumen Berbasis Inkuiri. Jurnal Inovasi Pendidikan Kimia, 2, No 1.

Septiani, D., \& Sumarni, W. (2015). Efektivitas Model Inkuiri Berbantuan Modul dalam Meningkatkan Pemahaman Konsep dan Keterampilan Generik Sains. Jurnal Inovasi Pendidikan Kimia, $8(2)$.

Soleh, M. Y., Santosa, S., \& Indrowati, M. (2014). Studi Komparasi Penerapan Model Pembelajaran Problem Based Jurnal Tadris Kimiya 3, 2 (Desember 2018): 145-157 

Inkuiri dan Verifikasi terhadap Keterampilan Generik Sains

Learning dan Inkuiri Terbimbing terhadap Keterampilan Proses Sains Siswa Kelas X SMA Negeri 3 Boyolali Tahun Pelajaran 2013/2014. BioPedagogi, 3(2), 1-11.

Syukri, S. (1999). Kimia Dasar 2. Bandung: ITB.

Yuliyanti, E., Hasan, M., \& Syukri, M. (2016). Peningkatan Keterampilan Generik Sains Dan Penguasaan Konsep Melalui Laboratorium Virtual Bebasis Inkuiri. Jurnal Pendidikan Sains Indonesia, 4(2), 76-83.

Zulfiani, H. (2014). Profil Keterampilan Generik Siswa SMA pada Model Pembelajaran Inkuiri Terstruktur (Structured Inquiry) Konsep Difusi dan Osmosis. FITK-UIN Syarif Hidayatullah Jakarta. 